\title{
RIGHTS OF THE MINORITY SHAREHOLDER TO THE CORPORATE DIVIDEND
}

\section{HUGH G. ISLEY*}

The difficulties and complexities of the problem confronting a court which is called upon by the minority shareholder of a corporation to invoke its equitable power to "force" the corporate dividend can be readily appreciated. Accordingly, a survey of the decisions on the subject reveals that the courts, motivated either by a realization of these difficulties or restrained by a recognition of their own incompetency to overrule the decisions of the corporate directors, have chosen a policy of great reluctance to interfere with the directors failure to declare the corporate dividend.

In spite of this reluctance there have been instances in which the courts have felt that an exercise of their equitable power was justified, the general rule being that the granting of dividends from the profits of a corporation is in the discretion of the directors subject to the interference of a court of equity for improper refusal. ${ }^{1}$ Thus, it has been held that invocation of the equitable power was justified where the directors, in refusing to declare the dividend, were guilty of "fraud or abuse of discretion," or where their refusal was arbitrary and unreasonable, ${ }^{3}$ or where they were withholding distribution by reason of adverse interest or bad faith. ${ }^{4}$ It is generally held, however, that actual fraud on the part of the directors need not be shown, and that equity may compel the dividend in the case of such arbitrary or wrongful withholding of dividends as to constitute a breach of trust, ${ }^{5}$ or where the dividend policy is

\footnotetext{
* 2d year law student, Duke University; A.B. Duke, 1951

1 For general discussion of this rule, see annotations at 55 A.I.R. 8, 76 A.L.R. 885, 109 A.L.R. 1381.

2 Jones v. Motor Sales Co., 322 Pa. 492, 185 Atl. 809 (1936).

8 Harry Channon v. Channon Co., 218 Inl. App. 397 (1920).

- Stevens จ. U.S. Steel, 68 N.J. Eq. 373, 59 Atl. 905 (1905); Tefft \%. Schaefer, 136 Wash. 302, 239 Pac. 837 (1925); Murray V. Beattie MPg. Co., 79 N.J. Eq. 322, 82 Atl. 1038 (1912).

55 A.L.R. 51.
} 
dominated by the personal interests of the directors rather than the corporate welfare. ${ }^{6}$

Admittedly, the benefit to be derived from the preceding judicial propositions is negligible when considered apart from the factual circumstances which brought the parties into court; hence it would seem that only through an analysis of these circumstances and the judicial considerations based thereon can meaning or semblance of order be drawn from the decisions. A study of the cases reveals that the decisions have turned on a number of considerations, which, for the purposes of analysis, may be divided into two categories: (1) those considerations relating to the needs of the particular corporation; and (2) those dealing with the status of the particular shareholder or shareholders seeking relief.

The basic consideration of the first group, as evidenced by the decisions, is the justification of the directorial retention of dividends in the light of the working or expansion capital needs of the corporation involved. This is as it should be, for if the refusal to declare a dividend can be justified on the basis of sound business policy, the court should not interfere. It is obvious, however, that no rule of thumb can be devised which will satisfactorily determine the amount of working capital which should be retained in a given business or the extent to which entrepreneurial expansion of the business should be carried. The needs vary greatly with the type of business; and even among businesses of the same type, there may be-due to differences in policy-great variations in the need for capital. It is perhaps with a realization of these complexities that the courts have been hesitant to interfere with directorial discretion and to compel a dividend merely on the basis of the existence of a large surplus. ${ }^{7}$ Thus, the courts have held that abnormal withholding of dividends was justified where the nature of the business was likely to require a great deal

\footnotetext{
Gottfried v. Gottfried, 73 N.Y.S.2d 692 (1947).

7 Trimble $\nabla$. American Sugar Refining Company, 61 N.J. 340, 48 Atl. 912 (1901).
} 
of working capital, ${ }^{8}$ or where the directors were justified in retaining dividends for use as expansion capital.9

In Raynolds v. Diamond Mitls Paper Co. ${ }^{10}$ the court in denying relief to the shareholders cautioned the directors:

"A court of equity is not without control over a corporation where the directors roll their profits into their business year after year until the great snowball has been magnified twenty diameters."

Accordingly, the dividend has been compelled where profits amounting to ten times the capital of the corporation had been accumulated; ;1 where no dividend had been paid by the defendant national bank for five years even though the period was marked by a considerable accumulation of profits ${ }^{12}$ and where there was no intent on the part of the directors to utilize the accumulated profits for proper re-investment. ${ }^{13}$

The second category of considerations, i.e., those dealing with the status of the shareholder seeking relief presents a more difficult, a less tangible problem; for the courts' main consideration must, in theory at least, lie with the needs of the corporation. The problem, however, is brought sharply into focus by the case of the non-cumulative, non-participating preferred shareholder; for to him a dividend once passed is gone forever and seldom reflects itself by an increase in the value of his holdings. While it is beyond the scope of this

\footnotetext{
${ }^{8}$ Gesell v. Tomahawk Land Co., 184 Wis. 537, 200 N.W. 550 (1924). $\mathrm{D}$ corporation was in the real estate business. But cf. Leviton v. N. J. Holding Co., 106 N. J. Eq. 517, 151 At1. 389 (1930) which held that defendant-realty company could not plow corporate profits back into the business indefinitely, even though there were opportunities for profitable re-investment.

- Raynolds v. Diamond Paper Mills Co., 69 N.J. Eq. 299, 60 Atl. 941 (1905).

10 Ibid.

11 Crichtón v. Webb Press Co., 113 La. 167, 36 So. 926 (1904). But cf. Hopkins v. Union Canvas Co., 104 Pa. Super. Ct. 264, 158 Atl. 301 (1932.) in which a similarly high ratio existed, but relief was denied on the grounds that the corporation "needed" expansion capital.

12 Hiscock v. Lacy, 9 Misc. 578, 30 N.Y.S. 860 (1894).

${ }^{2}$ Supra, note 3 . An interesting point relative to what constitutes a proper purpose for re-investment of corporate profits was raised in the leading case of Dodge v. Ford Motor Co., 204 Mich. 459, 170 N.W. 668 (1919), in which a decree compelling the dividends of $\$ 19,000,000$ was upheld on the grounds that the directors' intention to utilize the accumulated profits to reduce prices for the benefit of the public was not in line with the main purpose of the business-the benefit of the shareholders.
} 
treatment to consider the peculiar problems relating to the preferred shareholder's rights to the undeclared dividend, it should be noted that courts have looked with sympathy at his sometimes disadvantageous status and have strived to compel a dividend in his favor. ${ }^{14}$

A problem which is closely related to that of the noncumulative preferred shareholder is that presented by the life tenant shareholder who, for obvious reasons, is greatly interested in forcing the dividend before his interest expires. An additional complication is introduced into the picture when the directors of the corporation are the remaindermen of the interest held by the life tenant. In such a situation, it is evident that the adverse interest of the directors can foster a dividend policy most unfavorable to the life tenant; and the courts have not been blind to such a possibility. ${ }^{15}$ Thus, it has been judicially recognized that a plaintiff life tenant is entitled to hold the director-remaindermen to greater accountability of profits than a mere shareholder..$^{10}$

A factor which is pertinent to the considerations here involved and one for which there is slight judicial authority is that recognized in Raynolds v. Diamond Mills Paper Co. ${ }^{17}$ The court there distinguished between stock for which there was a ready market, and that of a closed corporation, the market for which is greatly limited. The owner of readily saleable stock can realize the acumulated profits in the form of the increased value of his holdings, while the stockholder in the closed corporation is forced to rely for the most part on the declaration of dividends. In view of the fact that the great majority of cases in which relief has been granted involved stock which was not readily marketable, it would seem that such a consideration plays no small part in the decisions of the courts.

The last factor concerning the shareholders' status, which has seemingly affected the decisions, is the past relationship

\footnotetext{
It See, Note, Compelling Declaration of Dividends by Contract Oon. struction, 39 ILL.L.REv. 90 (1944).

Is Ochs y. Maydole Hammer Co., 138 Misc. 665, 246 N.Y.S. 539 (1930);

Murray v. Beattie Mff. Co., 79 N.J.Eq. 322, 82 Atl. 1038, 1045 (1912).

16 Ochs v. Maydole Hammer Co., supra note 15.

I7 Supra, note 9.
} 
of the shareholder to the dividend policy. If the complaining shareholder has participated without objection in the receipt of dividends and has acquiesced in the accumulation of a large surplus, it has been held that he cannot later demand distribution of that surplus. ${ }^{18}$ Similarly, it has been held that if the complaining shareholder as a former director helped inaugurate a dividend policy, he will not later be heard to complain of the unfairness of that policy. ${ }^{10}$ It is submitted, however, that such holdings are questionable as to their general acceptability for it would not seem that a shareholder's approval of a dividend policy today should preclude his attacking its reasonableness or fairness tomorrow in the light of ever-changing business conditions.

While the preceding two categories of considerations offer some help in a preliminary analysis of the problem, they offer little aid in reconciling the decisions. A closer analysis of the decisions granting relief to the minority stockholders reveals that the main concern of the courts lies with considerations which fail to fit neatly into either of the categories; but rather cuts across both and, in the last analysis, seem to provide the basis for the conclusion that relief should be granted. This third group of considerations encompasses those instances in which there exists a relationship of conflicting interest between director and stockholder, resulting in a dividend policy fostered by the self-interest of the directors. For example, in Crichton $v$. Webb, ${ }^{20}$ the directors were withholding profits for the purpose of paying off corporate debts incurred in self-dealing contracts. Similarly, in Hiscock v. Lacy, ${ }^{21}$ there was evidence that no dividend had been declared in order to "freeze out" the minority and to pay excessive salaries to the majority shareholder group. Accordingly, relief has been granted where the majority of the directors combined to restrain dividends to keep a third director from getting his proportionate

\footnotetext{
1s Marks v. American Brewing Co., 126 La. 666, 52 So. 983 (1910).

10 Supra, note 2.

supra, note 11.

\& Supra, note 12.
} 
share of profits, ${ }^{22}$ and where there was fraudulent collusion between the directors and a bankrupt shareholder in an effort to prevent the latter's trustee from obtaining dividends. ${ }^{23}$ Relief has also been forthcoming when the withholding of dividends was accompanied by an increase of salaries, unreasonable commissions, and excessive expense accounts for the majority group. ${ }^{24}$

The recent case of Whittemore vs. Continental Mills ${ }^{20}$ involved a somewhat novel variation relating to conflicting interests between stockholder and director. It was alleged by the minority group that the directors were influenced by the majority stockholders to restrain dividends to avoid high-bracket income taxes. The plaintiff-stockholders further argued that continuation of such a policy might subject the corporation to a penalty under Section 102 of the Internal Revenue Code. ${ }^{26}$ The court granted relief.

The stockholder life tenant, director-remainderman problem touched on previously is pertinent here; for the adverse interest between stockholder and director is no small factor in the decisions of such cases. ${ }^{27}$ Similarly, agreements by director-shareholders of closed corporations providing that the stock of a deceased director shall become the property of the survivors on payment to the estate of an agreed sum raise a problem of adverse interest. In

\footnotetext{
2 Laurel Springs Land Co. V. Fougeray, 50 N.J.Eq. 756, 26 Atl. 886 (1893); Lawton v. Bedell, 71 At1. 490 (N.J.Ch. 1908).

23 In re Brantman, 244 Fed. 102 (2d Cir., 1917).

24 Jones $\vee$. Van Heusen Charles Co., 230 App. Div. 694, 246 N.Y.S. 204 (1930); Keough v. St. Panl Milk Co., 205 Minn. 96, 285 N.W. 809 (1939). 2598 F.Supp. 387 (D.Me. 1951).

28 \& 102 of the Internal Revenue Code which provides for a surtax on improperly accumulated corporate profits presents an interesting analogy to the problem here. T. D. 4914, 1939-2 Curr. BurL. 108, prescribed certain tests to determine whether the necessary intent to evade taxes was present. Indications of insufficient distribution of profts were: failure to distribute $70 \%$ or more of earnings; investment in securities or other property unrelated to normal business activitles; and loans made to shareholders or corporate officers. These con. giderations are not far removed from those involved in the immediate problem. See, Cannon v. Wiscassett Mills Company, 195 N.C. 119, 141 S.E. 344 (1928), in which the defendant corporation had invested its accumulated profits in low return securities.

er supra, note 15.
} 
such agreements it is often provided that during the period of payment, the stock is to be held by the estate as security for the amount due, and dividends therefrom-or a portion thereof-are to be paid to the estate. In the presence of such adverse interests between the beneficial shareholder and the corporate directors, the dividend has been compelled. ${ }^{28}$ Thus, there is much to be said for the proposition that while courts pay lip service to an examination of the capital requirements of the corporation in question or to the status of the particular shareholder, the adverse interest of the directors is often the keystone in the granting of equitable relief.

The previous discussion has been chiefly concerned with the problem involved, stripped of the alterations brought about either by charter provision or statutory modification. On close analysis, it would seem that very few cases actually turn on the presence of a statute or by-law provision; for in the last analysis the decision to pay dividends must lie within the discretion of the directors, and only in the event of what the court considers to be an abuse of that discretion will the equitable power to compel the dividend be invoked.

There is authority, however, to the effect that corporate by-law provisions offer grounds for relief where it would otherwise be unavailable. Thus, where the by-law contained a maximum figure for earned surplus and provided that on attaining that figure, dividends must be paid out of current earnings, it was held that the by-law was valid and could not be overridden by resolution of the directors to retain profits in the company. ${ }^{29}$ Also by-laws making dividends mandatory when capital would not be impaired thereby, have been invoked as a basis for affording relief., ${ }^{30}$ The

${ }^{23}$ Kassel v. Empire Tinware Co., 178 App.Div. 176, 164 N.Y.S. 1033 (1917).

$\Re$ Lydia Pinkham Medicine Co. v. Grove, 303 Mass. 1, 20 N.E.2d 482 (1939).

30 Crocker v. Waltham Watch Co., 315 Mass. 397, 53 N.E.2d 230 (1944). But cf. Koppel . Middle State Petroleum Corp., 197 Misc. 479, 96 N.Y.S. 2d $38(1950)$, in which the court denied relief in the face of similar provisions on the grounds that it was within the discretion of the directors to set up contingency reserves which absorbed the profits which would have been paid out as dividends under the provision. 
case of Leviton v. North Jersey Holding Company ${ }^{31}$ presents an interesting point in this respect. It was held there that a by-law expressly providing for re-investment of profits in real estate did not give the directors a right of perpetual re-investment. Thus, the courts seem prone to construe the by-law so as to impose only a reasonable restriction on the shareholders' right to demand a dividend, on one hand, and a reasonable restraint on the discretion of directors to withhold dividends on the other. It is open to question, however, whether such by-law provisions are the deciding factor; for it would seem that in most cases a similar decision would have been reached absent the bylaw provision.

Statutes governing the shareholders' rights to the corporate dividend fall into two categories: (1) those which codify the common law and leave the dividend policy within the discretion of directors $;^{32}$ and (2) those which make mandatory a declaration of dividends from earnings that are not reserved for working capital by the directors or stockholders. ${ }^{33}$ It should be noted that statutes of the first class, while generally providing that the dividend decision is within the discretion of the directors, have been construed by the courts to require a "good faith" discretion. ${ }^{34}$ Therefore, it would seem that these statutes effect little change in the common law.

The second type of statute, which has been adopted by New Mexico and North Carolina, presents an interesting problem. The statutes in the two states are almost identical, both apparently stemming from an $1896 \mathrm{New}$ Jersey statute which has since been replaced in New Jersey by one of the first category. ${ }^{35}$ Section 55-115 of the North Carolina General Statutes provides:

\footnotetext{
supra, note 8.

a N.J.Rev.StaT. 1937, 14:8-20; Vernon's Tex.Star. 1936, Art. 1329; Utar Code ANNo., 1943, 18-2-16(4).

*3 N.S.Gen.STAT. 1950, § 55-115; N.M.STAT. 1941, § 54-316.

3. Agnew V. American Ice Co., 2 N.J. 291, 66 A.2d 330 (1949).

36 A discussion of the early New Jersey statute appears in Stevens $v$. U.S. Steel Corp., 68 N.J.Eq. 373, 59 Atl. 905 (1905).
} 
"The directors of every corporation created under this chapter shall, in January of each year, unless some specified time for that purpose is fixed in the charter, or by-laws, and in that case at the time so fixed, after reserving, over and above its capital stock paid in, as a working capital for the corporation, whatever sum has been fixed by the stockholders, declare a dividend among its stockholders of the whole of its accumulated profits exceeding the amount reserved, and pay it to the stockholders on demand. The corporation may, in its certificate of incorporation or by-laws, give the directors the power to fix the amount to be reserved as working capital."

A superficial analysis would seem to indicate that the statute has provided the stockholders with an effective weapon to combat the autonymous powers of the directors. A more realistic approach, however, premised with the realization that in the great majority of cases in which relief is sought the directors either own controlling interests themselves or control the stockholder vote, reveals that the statute adds little-if anything - to the minority stockholders' common law rights. Compliance with the statute may be had by the reservation of working capital through a resolution of the stockholders; this usually presents little problem for the directors, who more often than not, control the ballot. A review of North Carolina cases reveals, however, that the court has relied upon the statute to grant relief when the reservation of working capital left unreserved profits in the corporate till. ${ }^{36}$ The cases imply that once the working capital has been reserved, the directors are under a legal duty to distribute the remaining profits as dividends, ${ }^{37}$ Note, however, that the legal duty can arise only when undistributed profits remain after the reservation of working capital. It would seem then that if the working capital reservation

es Cannon $\nabla$. Wiscasset Mills, supra, note 26.

37 Ibid. Dictum in Steele $\nabla$. Locke Cotton Mills Co., 231 N.C. 636, 58 S.E.2d 620 (1950) expresses this view: "Where accumulated profits of a corporation have heen ascertained in conformity with the statute, a legal duty devolves upon the directors to declare a dividend among the shareholders of the whole of the accumulated profits and to pay same to shareholders on demand." 
is within the control of the directors, the statute affords the aggrieved minority stockholder no help. Indeed, it is even arguable that the common law "good faith" restriction on the directorial discretion has been lost if the shareholder is limited to dividends payable out of profits unreserved for working capital. The North Carolina courts have handled this problem by requiring that the resolution authorizing the reservation of working capital meet the "good faith" standard. Hence in Amick v. Coble ${ }^{38}$ where no corporate action to reserve working capital was taken until after the suit for declaration of the dividend was commenced, the court found that there was sufficient evidence of bad faith to render the belated attempt of reservation of working capital invalid, thereby making the accumulated profits available for dividends. The court gave outward recognition to this approach in the recent case of Gaines v. Long Manufacturing Company ${ }^{39}$ where the court recognized that while the controlling authorities of a corporation are clothed with broad discretionary powers in fixing the amount of working capital, this discretion is not an unlimited one but must be exercised in good faith. Thus, it seems that the statute as construed by the North Carolina court effects little change in the good faith requirement at common law; for the same proof which establishes the bad faith of the refusal to declare the dividend at common law, will suffice to establish the bad faith of the resolution to reserve working capital under the statute. Admittedly, the statute aids the stockholder in forcing the dividend when the profits ir. question are not earmarked for working capital; but it is submitted that, as a practical matter, the cases in which relief is available under the statute and would not be at common law are few indeed.

\section{CONCLUSION}

It has been seen that the courts have been hesitant to interfere with the corporate dividend policy. This is, perhaps, as it should be, for the courts are ill equipped to

s 222 N.C. 484, 23 S.E.2d 854 (1943).

๓ Gaines v. Long Manufacturing Co., 234 N.C. 340, 67 S.E.2d 355 (1951). 
substitute their judgment for that of those who are closest to the problem. There is much to be said, however, for the position that under the present approach, the minority stockholder is burdened with an excessively heavy legal handicap in establishing the bad faith of the directors' refusal to declare dividends. There seems to be no ready remedy to the problem; but it is submitted that a possible solution lies in a change in the present law regarding presumptions and burdens of proof. While the present law attaches to the directorial decision a presumption of good faith, ${ }^{40}$ thereby shifting the burden of going forward to the shareholder, it would not seem out of reason to allow the plaintiff shareholder the benefit of a presumption of bad faith, once he has established the existence of profits from which dividends could be declared and has introduced evidence tending to show an adverse interest on the part of the directors. Such a change is not a complete reversal of the present law, for the shareholder would bear the burden of proving the availability of profits and the existence of the adverse interest. But it would serve to attach to these factors a presumption of bad faith thereby shifting the burden of justification to the directors, who seem in a much better position to bear it. While this solution raises problems of its own, it would seem to have advantages over an approach which casts the bulk of the burden on the stockholder who is seldom in command of facts which enable him to bear it. The directors, on the other hand, should have little difficulty in defending their refusal to declare dividends if it is grounded in a reasonably sound business policy.

to Wilson v. American Ice Co., 206 F. 736 (D.N.J. 1913); Mulcahy v. Hibernia Savings and Loan Society, 144 Cal.287, 77 Pac. 910 (1904). 